\title{
Assessment of the Risk of Microbial Contamination of an Urban Crop in the City of Daloa (Côte d'Ivoire): Case of Lettuce (Lactuca sativa L.)
}

\author{
Clément Kouassi Kouassi ${ }^{1,2}$, Athanase Kra Kouassi ${ }^{1,2}$, Mathurin Konan Yao $^{2,3}$, Gustave Adingra Kouassi ${ }^{1}$ \& \\ Rose Koffi-Nevry ${ }^{2}$
}

${ }^{1}$ Université Jean Lorougnon GUEDE, Département Biochimie-Microbiologie, Laboratoire Agrovalorisation, BP 150 Daloa, Côte D'Ivoire

${ }^{2}$ Université Nagui Abrogoua, Département des Sciences et Technologies des Aliments, Laboratoire de Biotechnologie et Microbiologie alimentaire, 02 BP 801 Abidjan 02, Côte d'Ivoire

${ }^{3}$ Université Peleforo Gon COULIBALY, Département de Biochimie-Génétique, Unité de formation et de Recherche des sciences Biologiques BP 1328 Korhogo, Côte d'Ivoire

Correspondence: Kouassi Kouassi Clément, Université Jean Lorougnon GUEDE, Département Biochimie-Microbiologie, Laboratoire Agrovalorisation, BP 150 Daloa, Côte D'Ivoire. E-mail: clemankoici@yahoo.fr

Received: March 15, 2019

doi:10.5539/jfr.v8n3p122
Accepted: April 4, 2019 Online Published: May 15, 2019

URL: https://doi.org/10.5539/jfr.v8n3p122

\begin{abstract}
The growing population of the city of Daloa, together with its growing urbanization, has a diversified need for food resources. Urban and periurban production of lettuce is a food resource for its people. This study was designed to assess the risk of microbial contamination. For the conduct of the study, first a survey was carried out on different sites of urban production to know the technical process of production. Then, mature lettuce, ready for sale and then consumed from a site, was subjected to microbiological characterization according to the standards in force. Microbiological analyzes revealed a high contamination. For mesophilic aerobic germs, the charges in CFU/g ranged between $1.7 \times 10^{7}$ and $6.7 \times 10^{7}$. The loads in CFU/g for yeasts and molds ranged from $3.4 \times 10^{5}$ to $9.3 \times 10^{5}$. As for fecal coliforms and enterobacteria, their loads ranged between $1.2 \times 10^{5}$ to $2.8 \times 10^{5}$ $\mathrm{CFU} / \mathrm{g}$ for the first and $7.2 \times 10^{5}$ to $10^{6} \mathrm{CFU} / \mathrm{g}$ for the second. These samples were contaminated with both Escherichia coli, Staphylococcus aureus $\mathrm{c}+$ and Salmonella $\mathrm{sp}$. The loads in E. coli and S. aureus c+ ranged between $9.4 \times 10^{4}$ and $1.8 \times 10^{5}$ for the first and $4 \times 10^{3}$ to $1.1 \times 10^{4} \mathrm{CFU} / \mathrm{g}$ for the second. Salmonella sp. was found with loads ranging from $6.1 \times 10^{4}$ to $8.2 \times 10^{4} \mathrm{CFU} / \mathrm{g}$. Empirical production process would increase the risk of microbial contamination. It is necessary to produce healthy lettuce for Daloa's consumers.
\end{abstract}

Keywords: contamination, Lactuca sativa, Daloa, Côte d'Ivoire

\section{Introduction}

Rapid urbanization and the strong concentration of urban populations have spawned a new form of agriculture, practiced in the urban and periurban areas of the major cities of West Africa. In Côte d'Ivoire, like other African countries, this new agriculture, dominated by market gardening, is booming (Dongmo et al., 2005; Soro et al. 2008; Ba \& Aubry, 2011). This urban and periurban agriculture is a revenue and employment generating activity practiced by urban vulnerable groups; thus contributing to the food security of the populations (Gomiero et al., 2011; Koffi et al., 2012; Loudit et al., 2017; Ba \& Cantoreggi, 2018). Daloa, the third most populous city in Côte d'Ivoire after Abidjan and Bouake, covering an area of $5.305 \mathrm{~km}^{2}$ and an estimated population of more than 288 000 in habitants, with its many administrative changes (commune, sub-prefecture, department and region, university town), is also confronted with this new form of agriculture (RGPH, 2014; Zah, 2015). This agricultural activity often practiced in the city center, faces enormous difficulties such as the thorny problem of urban pollution and the proximity of garbage and waste disposal sites of all kinds. Unfortunately, crops are being grown in difficult contexts, marked in particular by the lack of financial means for the supply of drinking water and synthetic fertilizers for soil fertilization; this often pushes market gardeners to use wastewater for irrigation and animal manure as fertilizer for the soil. These farming practices could favor a high contamination of soil and 
production tools by microorganisms, some of which may be harmful to human health according to several studies (Koffi et al., 2012; Pereira et al., 2013; Woldetsadik et al., 2017). Productions resulting from these cultivation practices, especially market garden produce, contaminated by pathogens can be dangerous for the consumer (Koffi et al., 2011; Alio et al., 2017). Based on the work of Patterson et al. (2010) and those of Blaak et al. (2015), the consumption of such cultures constitutes a potential risk factor for infection. Contamination of vegetables is one of the potential risks of infection with enteropathogenic bacteria such as Salmonella and Escherichia coli. This contamination occurs from an environmental, animal or human source at the time of planting, harvesting or handling vegetable prior to consumption (Cobbina et al., 2013; Wognin et al., 2013). Considered as a contamination of plant surfaces, recent work has shown that certain pathogens such as salmonella are able to infect and multiply in the mesophyll of certain plants such as lettuce (Kroupitski et al., 2009; Guchi et al., 2010; Pelletier et al., 2011; Schikora et al., 2011). In Daloa, lettuce is cultivated in urban, peri-urban areas on marshy sites and in shallows at the very heart of some of the central districts of the city. Thanks to its incomparable nutritional richness and the fibers it contains, lettuce (Lactuca sativa L.) is of paramount importance in the dietary habits of the population and also for the proper functioning of the organism (Zhang et al., 2009; Berger et al., 2010; Pereira et al., 2013). It is one of the most popular and most consumed vegetables in the world, often the main ingredient in salads (Koffi et al., 2011; Maffei et al., 2013). However, to our knowledge, no exhaustive study of the production route, the microbiological quality of the urban production lettuce in Daloa has not been the subject of any scientific study. In addition, there is little data available on urban lettuce producers. The overall objective of this study was to assess the risk of microbial contamination of lettuce produced in the city of Daloa. The information obtained can be used to sensitize producers to improve the route and sanitary quality of lettuce (Lactuca sativa L.) produced in the city of Daloa or in other cities where urban and periurban agriculture were practiced.

\section{Method and Material}

\subsection{Presentation of the Study Site}

The study area is the town of Daloa, located in the central west of Côte d'Ivoire between $6^{\circ} 3^{\prime}$ north latitude and $6^{\circ} 27^{\prime}$ west longitude. The study site is a low-lying geographic coordinates $06^{\circ} 27^{\prime} 33.52^{\prime \prime}$ west longitude and $06^{\circ} 53^{\prime} 35.92$ " latitude north, located in the center of the city. Figure 1 below shows the geographical location of the study area.

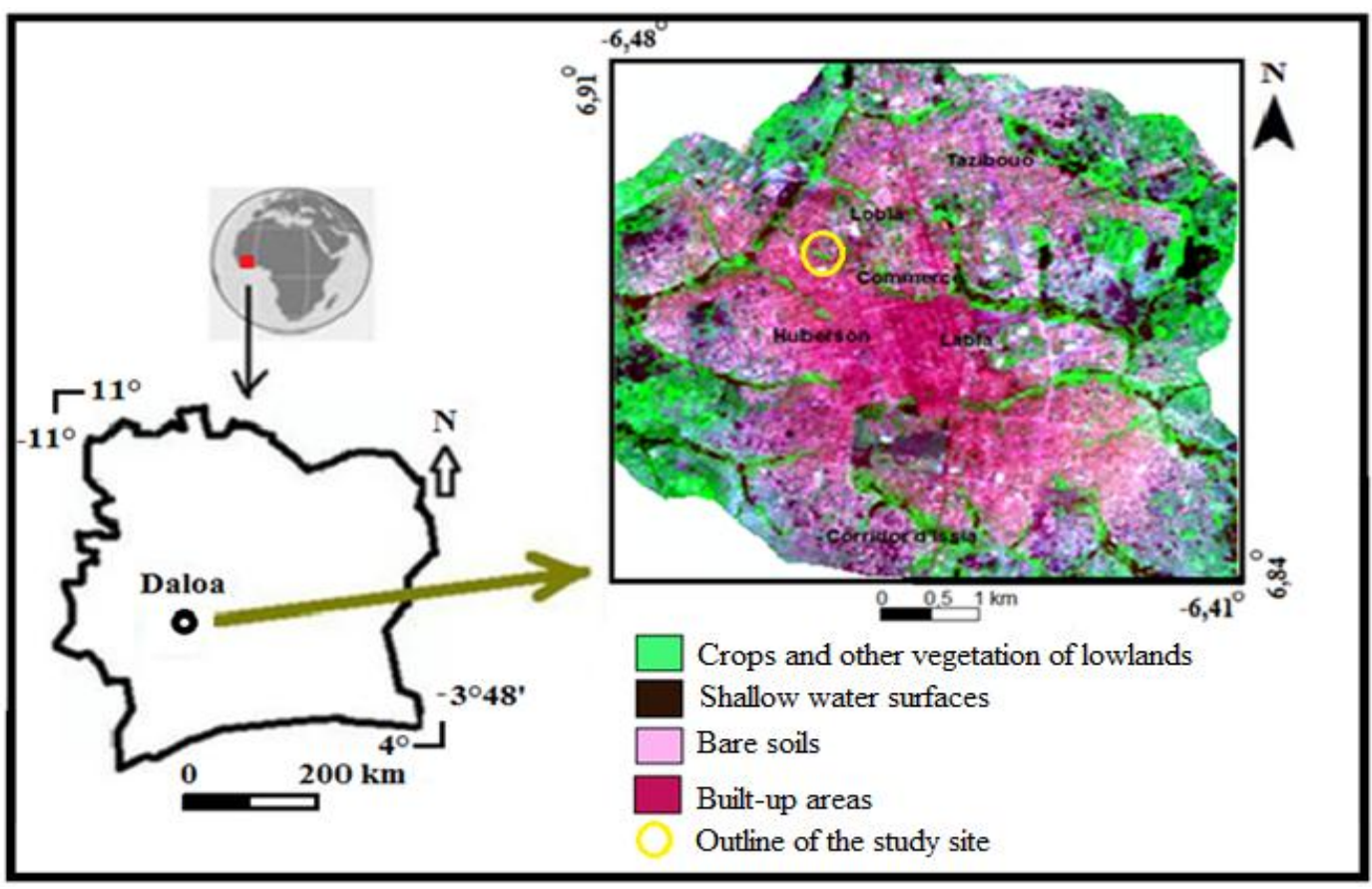

Figure 1. Map of the city of Daloa presenting the study site

\subsection{Diagnosis and Characterization of Urban Production of Lettuce in Daloa}

A survey with a questionnaire was developed to collect information on urban lettuce production sites in the city 
of Daloa. This survey first gave information on the profile of the producers (gender, age, nationality, level of study) and then on the technical itinerary of the urban production of lettuce (source of irrigation water, type amendment). The survey was conducted from 25-10-2017 to 28-12-2017 at four urban and periurban production sites in the city of Daloa. The people surveyed are of two kinds, of all levels of study and of all social strata. In total, the survey covered 31 lettuce producers.

\subsection{Microbiological Characterization}

\subsubsection{Sampling}

On the site, three different lettuce beds are a study block. For each block, were selected three different samples composed of three feet of lettuce at maturity taken at random on the three boards. These harvested samples are packaged in stomacher sachets. Samples once taken are stored in a cooler with dry ice and transported to the laboratory for analysis. These analyses were done at the Laboratory of Host-Microorganisms and Evolutions Interactions (LIHME) of University Jean Lorougnon Guede.

\subsubsection{Methods of Analysis}

Several methods were used in this study. Buffered Peptone Water (BPW) broth was used in the preparation of stock solutions as described in ISO 6887-4: 2011. Decimal dilutions were performed with Tryptone Sel broth as recommended in ISO 6887-1: 1999. Plate Count Agar (PCA) was used to count mesophilic aerobic flora at $30^{\circ} \mathrm{C}$ for $72 \mathrm{~h}$ as recommended in NF/ISO 4833: 2003. Enterobacteria count was performed at $37^{\circ} \mathrm{C}$ for $24 \mathrm{~h}$ on Violet Red Neutral Bile Glucose (VRBG) agar according to ISO 21528-2: 2004. Violet Neutral Bile Lactose (VRBL) agar was used for fecal coliforms count at $44^{\circ} \mathrm{C}$ for $24 \mathrm{~h}$ as described in ISO 4832: 2006. For the search, isolation and enumeration of Salmonella sp, media Buffered Peptone Water (BPW), broth Rappaport of Vassiliadis Soya Broth and Hecktoen Enteric Agar were used as described in the reference standard NF/ISO 6579:2002 Amd 1: 2007. Baird-Parker Agar with Telluride Egg Yolk and 0.2\% Sulphamethazine served the identification of Staphylococcus aureus at $37^{\circ} \mathrm{C}$ for $48 \mathrm{~h}$ according to the French standard NF/ISO 6888: 2004. Rapid'E coli 2 agar served the isolation and enumeration of Escherichia coli at $44^{\circ} \mathrm{C}$ for 24 to $48 \mathrm{~h}$ as recommended in standard NF/ISO 16140: 2013. Yeasts and molds were counted with Sabouraud agar chloramphenicol $25^{\circ} \mathrm{C}$ for 5 days according to the NF/ISO 16212: 2011 standard. The different culture media used were prepared according to the manufacturers' instructions.

\subsubsection{Preparation of the Stock Solution and Decimal Dilutions}

Twenty-five grams ( $25 \mathrm{~g}$ ) of lettuce's sample was aseptically transferred to an Erlenmeyer flask containing 225 $\mathrm{mL}$ of sterile (BPW) medium to prepare the stock solution. Everything is carefully mixed, taking care to soften the leaves with the fingers 2 to 3 minutes. After a 1 hour rest on the bench at room temperature, the stock solution was decimally diluted in sterile Tryptone Salt medium up to $10^{6}$.

\subsubsection{Inoculations and Incubations}

\section{Research of mesophilic aerobic germs, yeasts and molds, fecal coliforms, enterobacteria and Escherichia coli}

According to the prescriptions of the standards adopted, the pour plate method was applied. Thus, one milliliter $(1 \mathrm{~mL})$ of the diluted lettuce sample to be analyzed is aseptically transferred to a sterile Petri dish and mixed with $20 \mathrm{~mL}$ of the respective agar. After solidification, the dishes are inverted and incubated at temperatures as given in the respective standard. Three Petri dishes were inoculated per dilution. The characteristic colonies according to the different media are then counted taking into account the calculation standard (NF/ISO 7218: 2007).

\section{Research of Staphylococcus aureus}

The surface spreading method was used for the detection of $S$. aureus. It consisted of taking $0.1 \mathrm{~mL}$ of the stock solution or a dilution of the lettuce sample to be analyzed, using a sterile pipette, and transferring to a Petri dish containing the Baird Parker agar medium already poured and solidified. The dilution is spread on the agar using a spreader rake. These manipulations are all performed under aseptic conditions near the Bunsen burner flame. Petri dishes are then inverted and incubated at $37^{\circ} \mathrm{C}$ for $48 \mathrm{~h}$. Two plates of Petri were seeded by dilution. Black colonies with a clear halo (action of lecithin) and an opaque zone (action of lipase) are counted (15-150 characteristic colonies) taking into account the dilution.

\section{Highlighting Salmonella sp}

It is done in three stages. Pre-enrichment is performed by incubating the stock solution at $37^{\circ} \mathrm{C}$ for $24 \mathrm{~h}$. The enrichment consisted of taking $0.1 \mathrm{~mL}$ of the stock solution (pre-enriched) and transferred to a tube containing 
$10 \mathrm{~mL}$ of Vassiliadis Rappaport previously prepared and sterilized. After homogenization, the tube is incubated at $42^{\circ} \mathrm{C}$ for $24 \mathrm{~h}$. Finally the isolation was carried out from the enrichment medium incubated on a solid selective medium: Hecktoen agar. A drop is taken using a Pasteur pipette and then seeded by streaks on the surface of the Hecktoen agar. The dish is incubated at $37^{\circ} \mathrm{C}$ for $24 \mathrm{~h}$, and sometimes even for $48 \mathrm{~h}$, in the absence of characteristic colonies after the first incubation. On Hecktoen agar, the typical Salmonella colonies observed are green or blue with a black center.

\section{Enumeration}

The number of Colony Forming Units per milliliter of sample (CFU/g) from the number of colonies obtained in the Petri dishes is carried out according to standard NF/ISO 7218: 2007.

$$
N=\frac{\Sigma C i}{\left(N_{1}+0.1 N_{2}\right) d \cdot V}
$$

$\Sigma \mathrm{Ci}$ : Sum of characteristic colonies counted on all retained Petri dishes;

N1: Number of Petri dishes retained at the first dilution;

N2: Number of Petri dishes retained at the second dilution;

d: Dilution rate corresponding to the first dilution;

$\mathrm{V}$ : Inoculated volume $(\mathrm{mL})$;

$\mathrm{N}$ : Number of microorganisms (CFU/g).

\section{Standards for assessing the microbiological quality of lettuce}

The microbiological quality assessment standards for lettuce are taken from the "Microbiological Criteria for Foodstuffs Guidelines for Interpretation of 2015 of Luxembourg"; supplemented by the normative reference of the microbiological criteria of human foods (C.E. $n^{\circ} 2073 / 2005$ ).

\section{Statistical analyses}

Statistical analyzes were conducted with the Statistica, 99 Edition. The different parameters analyzed were then subjected to an analysis of variance (ANOVA) with the software Statistica, 99 Edition. For this purpose, a single-factor ANOVA and Duncan's multi-extended tests were used. ANOVA was used to test, on the one hand, the variability between the different samples. As for Duncan's test, he later made it possible to first locate the differences between the samples and then the differences between them. Statistical differences with P-values under 0.05 were considered significant.

\section{Results}

\subsection{Characteristics of Urban Producers of Lettuce and Diagnosis of Their Production Process}

The profile of the urban lettuce producers of the different sites investigated is summarized in Table 1. Lettuce is produced by both genera. It is dominated by the female gender $(58.1 \%)$ against $41.9 \%$ for the male gender. The age of the producers varies between 30 and 60 years. They are mostly Ivorian $(58.1 \%)$ and have a low level of education.

Table 1. Profile of urban producers and characteristics of lettuce production

\begin{tabular}{llll}
\hline & & Frequency & Percentage (\%) \\
\hline \multirow{2}{*}{ Age (years) } & $<30$ years & 7 & 22,6 \\
& $30-60$ years & 14 & 45,2 \\
& $>60$ & 10 & 32,3 \\
\hline \multirow{2}{*}{ Gender } & Male & 13 & 41,9 \\
& Female & 18 & 58,1 \\
\hline \multirow{2}{*}{ Nationality } & Ivorian & 18 & 58,1 \\
& Burkinabe & 8 & 25,8 \\
& Malian & 5 & 16,1 \\
\hline \multirow{3}{*}{ Level of study } & Illiterate & 25 & 80,6 \\
& Primary & 3 & 9,7 \\
& Secondary & 3 & 9,7 \\
\hline \multirow{2}{*}{ Agricultural inputs } & Surface water & 31 & 100 \\
& Poultry manure + chemical & & 48,4 \\
& fertilizers & 15 & 51,6 \\
\hline
\end{tabular}




\subsection{Technical Process of Urban Lettuce Production}

The technical process of producing lettuce from the different study sites investigated is summarized in the diagram below (Figure 2). According to the survey, the quantities of chemical or natural fertilizer used are not quantified, so the earth planks for the crops are made by punching.

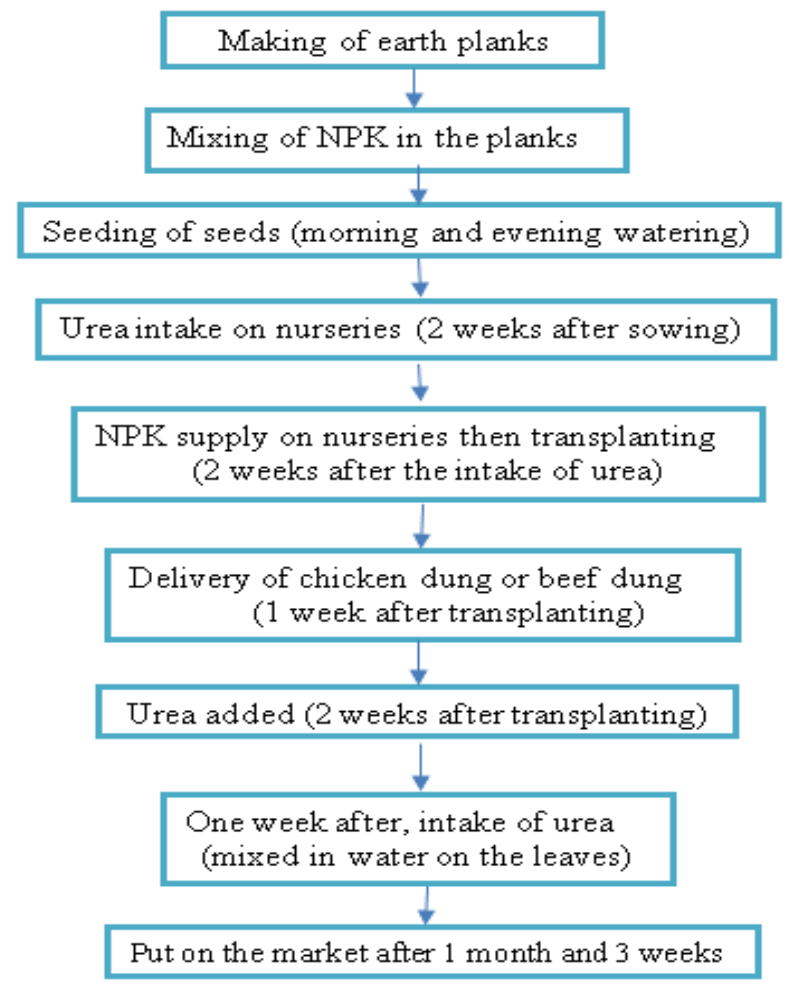

Figure 2. Urban production process of lettuce (Lactuca sativa L.)

\subsection{Microbiological Characteristics of the Lettuce Produced}

\subsubsection{Presence of Microflora in Lettuce}

The microbiological study assessed the level of microbiological contamination of lettuce produced in urban areas of Daloa. Microbiological analyzes made it possible to count microorganisms; major alteration microfloras and/or floras suggestive of a deficit in good production and hygiene practices of lettuce produced in urban areas in Daloa. These are fungal flora (yeasts/molds), mesophilic aerobic germs, fecal coliforms and enterobacteria. All samples from the study site were heavily contaminated by these different microfloras. In addition, all charges (CFU/g) of the flora were all well above the expected microbiological quality standards. The CFU/g load for yeasts and molds ranged from $3.4 \times 10^{5}$ to $9.3 \times 10^{5}$ while the standard predicts $10^{4}$ (Figure 3 ). The loads of the fungal flora of the different study blocks were unequally distributed and therefore statistically different $(p>0.05)$ from one block to another. For mesophilic aerobic germs, the CFU/g load ranged from $1.5 \times 10^{7}$ to $6.3 \times 10^{7}$ while the standard indicated $3.10^{6}$ (Figure 4). As for fecal coliforms and enterobacteria, their loads ranged between $1.2 \times 10^{5}$ to $2.8 \times 10^{5} \mathrm{CFU} / \mathrm{g}$ for the first and $7.2 \times 10^{5}$ to $1.1 \times 10^{6} \mathrm{CFU} / \mathrm{g}$ for the second while the standards are $10^{2}$ $\mathrm{CFU} / \mathrm{g}$ and $10^{4} \mathrm{CFU} / \mathrm{g}$ respectively (Figures 5 and 6). These microfloras varied from one block to another and therefore statistically different $(p>0.05)$. The B12 block samples were more contaminated by the mesophilic aerobic germs $\left(6.3 \times 10^{7} \mathrm{CFU} / \mathrm{g}\right)$, those of the B5 block contained the highest yeast and mold load $\left(9.3 \times 10^{5}\right.$ $\mathrm{CFU} / \mathrm{g})$; the B8 block samples contained both the largest fecal coliforms and enterobacteria load $\left(2.8 \times 10^{5} \mathrm{CFU} / \mathrm{g}\right)$ for the first and $\left(10^{6} \mathrm{CFU} / \mathrm{g}\right)$ for the second. 


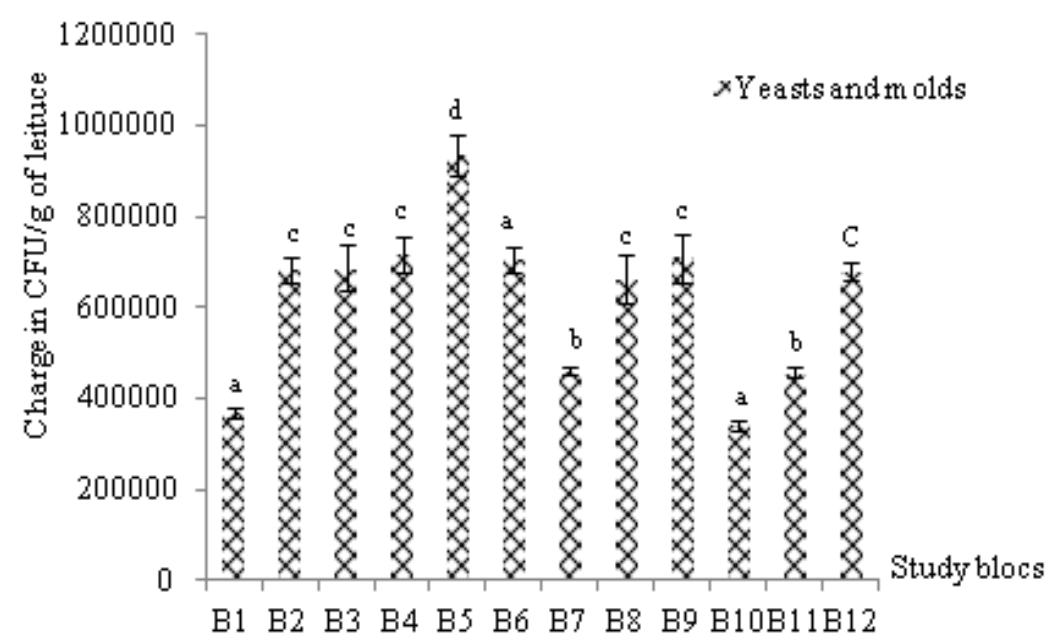

Figure 3. Numbers in CFU/g of yeasts and molds in lettuce according to the study blocks. Values with the same letters are not significantly different $(\mathrm{P}>0.05)$

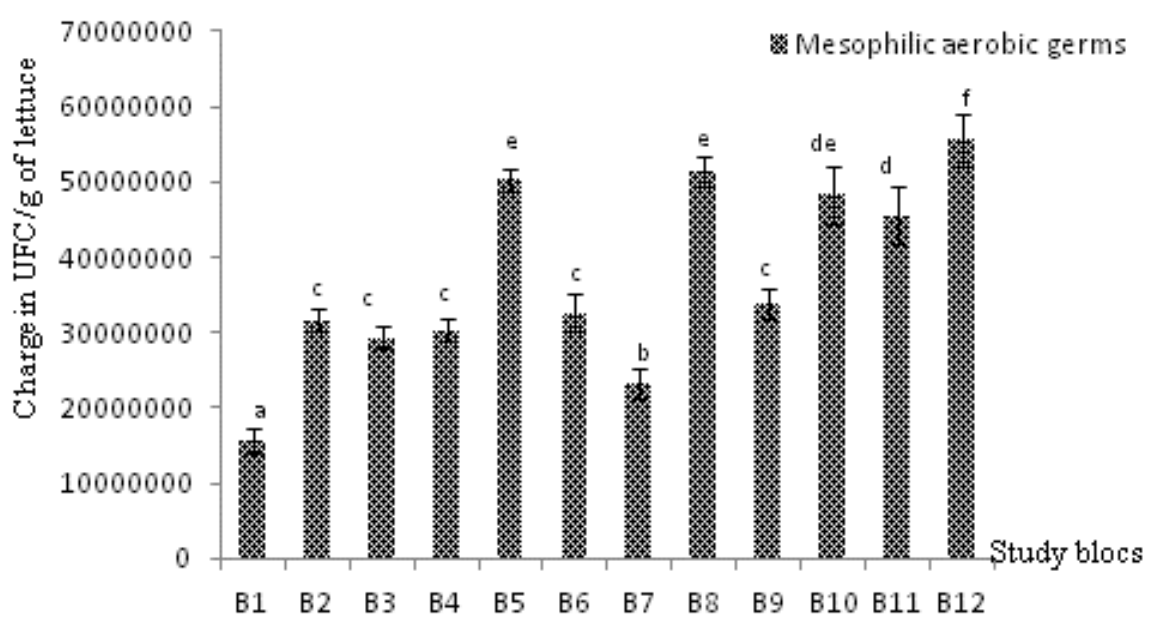

Figure 4. Numbers in CFU/g of mesophilic aerobic germs in lettuce according to the study blocks. Values with the same letters are not significantly different $(\mathrm{P}>0.05)$

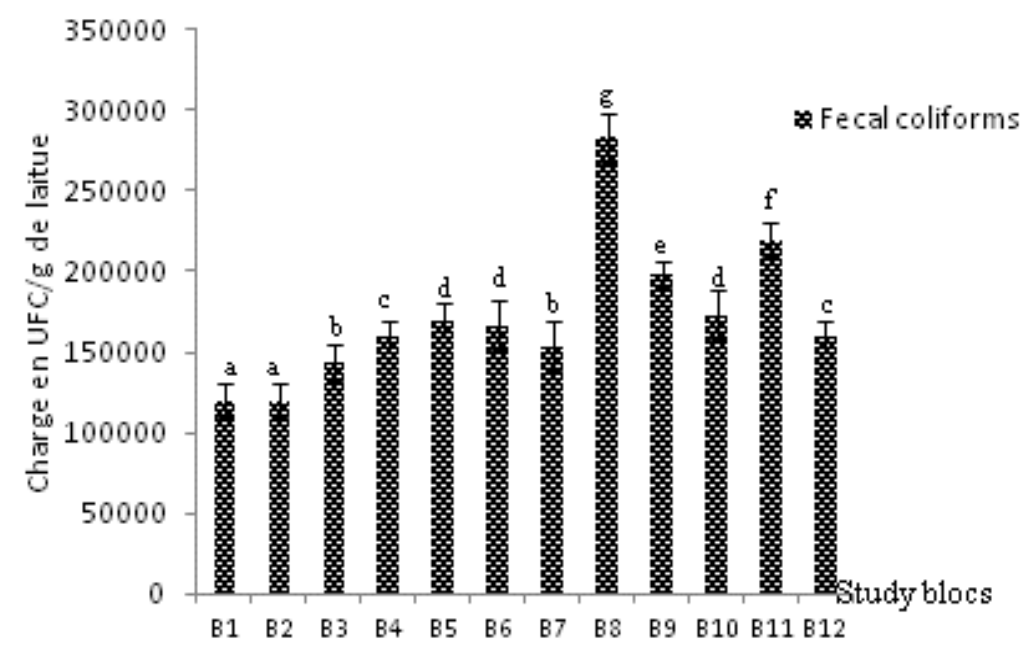

Figure 5. Numbers in CFU/g of fecal coliforms in lettuce according to the study blocks. Values with the same letters are not significantly different $(\mathrm{P}>0.05)$. 


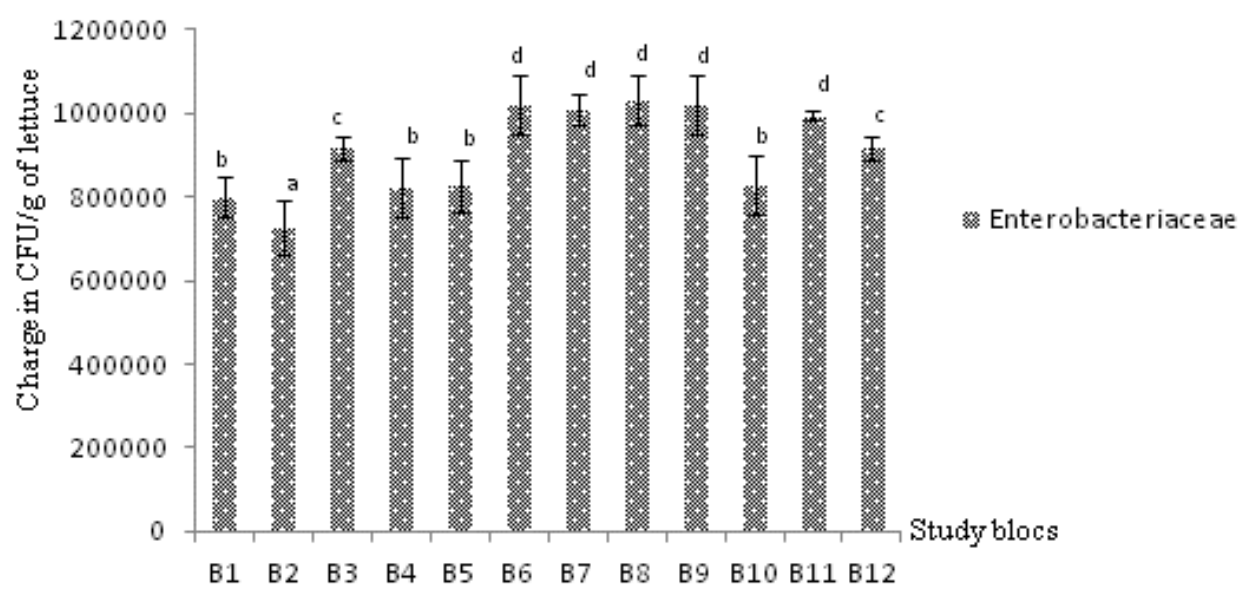

Figure 6. Numbers in CFU/g of enterobacteriaceae in lettuce according to the study blocks. Values with the same letters are not significantly different $(\mathrm{P}>0.05)$

\subsubsection{Presence of Pathogenic Species}

Lettuce from the investigated site was contaminated with pathogenic bacterial species including Escherichia coli, Salmonella sp and Staphylococcus aureus coagulase positive. Worse, all the samples from the twelve study blocks contained all three species at the same time, with heavy loads exceeding the microbiology standards for fresh vegetables. The CFU/g number for $E$. coli ranged from $9.4 \times 10^{4}$ to $1.8 \times 10^{5}$, whereas the standard predicts 10 to $10^{2}$ (Figure 7). For S. aureus coagulase +, the charges in CFU/g ranged from $5.9 \times 10^{4}$ to $1.4 \times 10^{5}$ while the standard indicated $10^{2}$ (Figure 7). Where all the standards in food microbiology on Salmonella sp are a total absence in $25 \mathrm{~g}$ of food, there were loads of $6.1 \times 10^{4}$ to $8.2 \times 10^{4} \mathrm{CFU} / \mathrm{g}$ for the lettuce samples of the different study blocks (Figure 7). The charges for E. coli, Salmonella sp and S. aureus coagulase positive from the different study blocks were unevenly distributed from one block to another. These loads were therefore statistically different $(\mathrm{p}>0.05)$ in the different blocks.

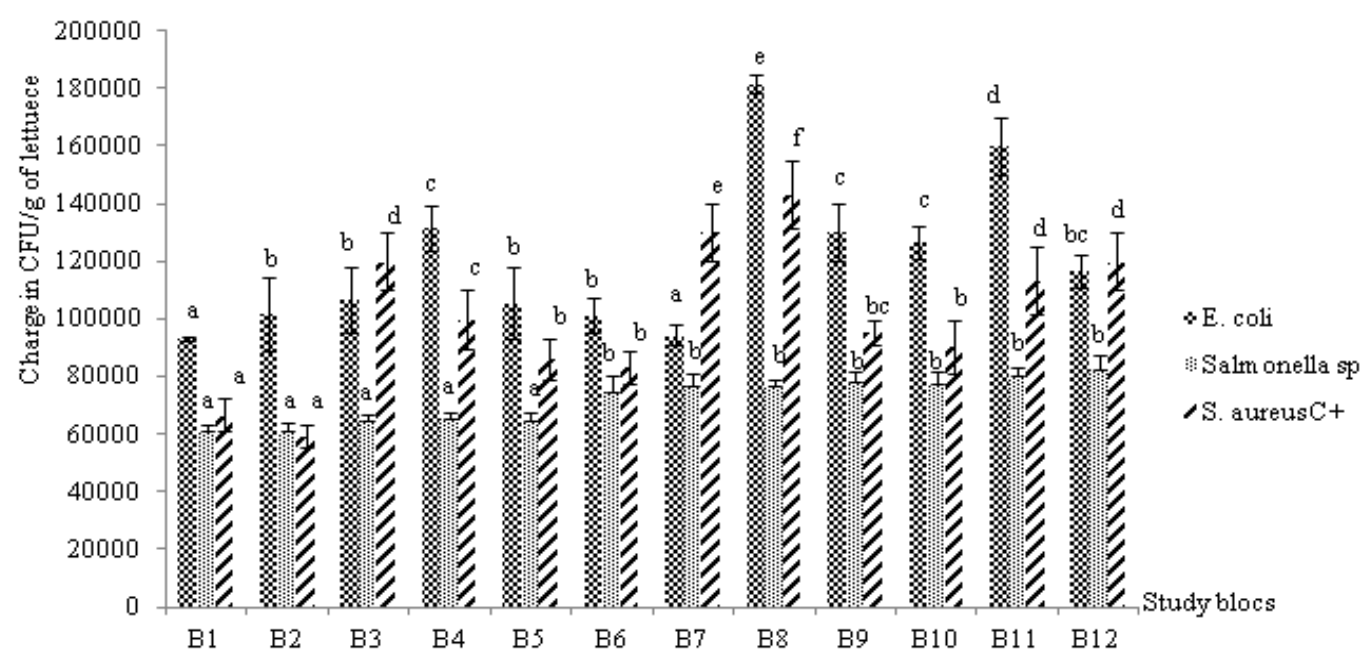

Figure 7. Numbers in CFU/g of pathogenic bacterial species in lettuce according to the study blocks. Values with the same letters are not significantly different $(\mathrm{P}>0.05)$

\section{Discussion}

The production of lettuce for the consumption of the people of the city of Daloa is urban. This activity was practiced by adults aged between 30 and 60, then dominated by the female gender (58.1\%) against (41.9\%) for men. These data differ from other data provided in other similar studies. Indeed, the works of Ackerson \& Awuah (2010) and those Kenmongue et al. (2010) carried out in Ghana and Cameroon respectively, urban and periurban market gardening was dominated by men and the majority of producers were between 24 and 68 years old. Urban and periurban production of lettuce farmers in Abidjan was also dominated by men (83\%) according to 
Koffi et al. (2012). If the age of producers between 30 and 60 years could be explained by the arduous nature of market gardening, the sudden dominant appearance of women could have a purely local explanation. In fact, in agricultural areas dominated by cash crops (coffee or cocoa); men's main activity, food crops such as vegetable crops are left to women. Urban lettuce producers in Daloa were predominantly Ivorians (58.1\%), unlike those in Abidjan who were dominated by non-nationals $(88.7 \%$ ) in a similar study (Koffi et al., 2012). The preponderance of nationals in this study is explained by the fact that agriculture is still the main activity in the deep country (Daloa) unlike the big capitals like Abidjan where the activities are much diversified. The high rate of illiterate producers $(80.6 \%)$ results from the high rate of illiteracy among the populations in the study area (61.9\%) according to (RGPH, 2014). In addition, a study on market gardening in Bouake (central Côte d'Ivoire) revealed that this activity was practiced by people with no education (Fondio et al., 2011). The main inputs for production were either poultry manure or a mix of dung, cow dung and chemical fertilizer. In addition, all producers $(100 \%)$ used surface or runoff water for watering lettuce. These same risky practices have been noted in other studies. In a study of the diversity and dynamics of Salmonella isolated from lettuce in Niger, soil amendments were mainly cow dung and chemical fertilizer (Alio et al., 2017). Exclusive use of surface water or gutters was also reported. In studies on perceptions of risk of contamination of urban and periurban crops, in Accra (Ghana), (Keraita et al., 2008) as in Belgium (Holvoet et al., 2014a), the majority of producers also used surface water or sewage for watering vegetables. The technical process of lettuce production practiced by urban producers was therefore empirical and unconventional or unknown. Some crucial provisions on the boards for a good production (width, length and spacing between boards) were royally ignored by these producers. In addition, no initial disinfection of the plants was carried out to avoid feathers, due among other things to fungi, insects and nematodes. In addition, soil amendments (fed with poultry and cow dung) were not processed and were used without precautions. All these facts are due to the low level of education of producers. The survey revealed that only about 20\% were educated. Amponsah-Doku et al. (2010), Soendjojo (2012) and Woldetsadik et al. (2017) also reported empirical or artisanal production techniques in their studies of urban and periurban market gardeners. The informal nature of this agriculture, the high level of illiteracy and the lack of training programs on good practices in urban farming could justify the behavior of producers who were not aware of the risks of contamination from gardening practices. These farming practices would make lettuce susceptible to contamination, including microbial contamination.

Microbiological analyzes have shown the contamination of lettuce produced at the study site. The lettuces of the different blocks were heavily contaminated by different flora including mesophilic aerobic germs, total coliforms, enterobacteria and yeasts and molds. The same flora had also been identified in urban production lettuce in other works (Mohammad et al., 2013). Similarly, Koffi et al. (2011), Mngoli \& Ng'ong'ola-Manani, (2014) and Akusu et al. (2016) isolated enterobacteria in lettuce in similar studies in Côte d'Ivoire, Malawi and Nigeria, respectively. The strong presence of these microfloras would translate into a marked deficit of good production and hygiene practices in the study site. High loads of these microfloras were also reported in other studies. Fecal coliforms were found in lettuce at production sites with loads ranging from $10^{3}$ to $10^{5} \mathrm{CFU} / \mathrm{g}$ and $10^{3}$ to $10^{4}$ CFU/g respectively, in Ghana in the works of Cobbina et al. (2013) and Ethiopia those Woldetsadik et al. (2017). Mesophilic aerobic germs $\left(3 \times 10^{5}\right.$ to $\left.1.1 \times 10^{6} \mathrm{CFU} / \mathrm{g}\right)$ and fungal flora $\left(2 \times 10^{3}\right.$ to $\left.2 \times 10^{4}\right)$ were reported in lettuce grown in Romania (Soendjojo, 2012). The site of this study, located in downtown Daloa and in shallow water, regularly receives wastewater, sewage and gutter water on a continuous basis without any treatment. In addition, these waters are either directly used for watering or they communicate directly in the surface waters of the lowlands that were used for this purpose. These waters, once contaminated would therefore be the source of contamination of lettuce produced. Several studies have reported this form of contamination. For Koffi et al. (2011) in Côte d'Ivoire, Abbou et al. (2014) in Morocco and Holvoet et al. (2014b) in Belgium, irrigation water from urban vegetable crops was the main source of microbial contamination of production. Coagulase positive Staphylococcus aureus has been reported in work in lettuce in Brazil (César et al., 2015). In the present study, the presence of enterobacteriaceae could be due to the precarious hygienic conditions in which these leafy vegetables are grown as already stated by other authors Amoah et al. (2007) and Koffi et al. (2012) after work on vegetables produced in urban areas or periurban. The urban lettuce producers of the investigated site used large quantities of poultry droppings (sometimes fresh), and beef dung as fertilizer for soil fertilization. This agricultural practice would favor permanent fecal contamination, hence the strong presence of fecal germs such as E. coli, Salmonella sp. The presence of these species has already been reported in several similar studies (Petterson et al., 2010; Schikora et al., 2011; Koffi et al., 2012; Jensen et al., 2015; Traoré et al., 2015). In a similar study in Ghana, the load of $E$. coli counted in lettuce on an urban site ranged from $10^{3}$ to $10^{4} \mathrm{CFU} / \mathrm{g}$ (Cobbina et al., 2013). In New Zealand, S. aureus was counted in lettuce from various production systems with feeds ranging from $10^{2}$ to $10^{3} \mathrm{CFU} / \mathrm{g}$ (Wadamori et al., 2016). Salmonella sp (0 to $\left.10^{4}\right)$ loads have been found 
recently in urban lettuce production in Ghana (Abakari et al., 2018). The high contamination of lettuce is also due to soil that has been heavily contaminated by the presence of dumpsites in the area, surroundings in addition to wastewater. Indeed, human excrement, farm animals such as oxen, sheep, other animals (lizards, migratory birds, dogs and cats) are constantly straying there. Their excreta are carried by rain runoff to soils, wells and other water sources used for watering. The urban lettuce of the investigated site would be a source of microbiological hazards, which would cause multiple infectious diseases such as diarrhea, gastroenteritis, typhoid and paratyphoid fevers. Its consumption constitutes a real risk of infection or a source of food poisoning which can lead to a public health problem.

\section{Conclusion}

Urban agriculture is a major source of lettuce (Lactuca sativa L.) for urban populations, as is the case in Daloa. The assessment of the risk of microbial contamination revealed that consumption of lettuce (Lactuca sativa $\mathrm{L}$.) from urban production in the city of Daloa would pose a risk to the health of consumers. High loads of microflora reflecting a deficit of good production and hygiene practices such as fecal coliforms, enterobacteria, mesophilic aerobic germs, yeasts and molds have been discovered. Pathogenic bacterial species such as Escherichia coli, coagulase positive Staphylococcus aureus and Salmonella sp were detected in all samples from the 12 blocks of the investigated site. The consumption of this lettuce would present a real danger to the health of consumers. The profile of producers, the upstream empirical production route and the difficult production conditions would increase the risk of microbial contamination and even other types of contamination. Thus, the competent authorities must raise awareness and raise awareness of the health risks to consumers. Establishing regulations for urban agriculture could limit the risk of contamination. An organization of urban agriculture with good training in agricultural production routes would contribute to the food security of urban populations and create jobs for urban vulnerable groups. Health education would be needed to prevent the health risks of consuming urban lettuce and to prevent possible foodborne infections. Good communication about these identified hazards would help the well being of consumers.

\section{Acknowledgments}

We thank these brave urban producers of the Daloa City for lettuce for the sake of this study.

\section{References}

Abakari, G., Cobbina, S. J., \& Yeleliere, E. (2018). Microbial quality of ready-to-eat vegetable salads vended in the central business district of Tamale, Ghana. International Journal of Food Contamination, 5, 3. https://doi.org/10.1186/s40550-018-0065-2

Abbou, B. M., Fadil, F., \& Hadji, E. M. (2014). Évaluation de la qualité des cours d'eau de la ville de Taza utilisés dans l'irrigation des cultures maraîchères (Maroc). Journal of Applied Biosciences, 77, 6462-6473. https://doi.org/10.4314/jab.v77i1.7

Ackerson, N. O. B., \& Awuah, E. (2010). Urban Agriculture Practices and Health Problems among Farmers Operating on a University Campus in Kumasi, Ghana. Field Actions Science Reports. Retrieved from http://factsreports.revues.org/451

Akusu, O. M., Kiin-Kabari, D. B., \& Wemedo, S. A. (2016). Microbiological quality of selected street vended foods in Port Harcourt metropolis, Rivers State, Nigeria. Sky Journal of Food Science, 5(2), 008-11.

Alio, S. A., Inoussa, M. M., Bakasso, Y., \& Samna, S. O. (2017). Diversité et dynamique des Salmonella isolées de la laitue (Lactuca sativa L.) dans les cultures maraîchères au Niger (Afrique de l'ouest). Journal of Applied Biosciences, 119, 11917-11928. https://doi.org/10.4314/jab.v119i1.8

Amoah, P., Drechsel, P., Henseler, M., Abaidoo, R. C. P., Drechsel, P., \& Kondrasen, F. (2007). Irrigated urban vegetable production in Ghana: microbiological contamination in farms and markets and associated consumer risk groups. Journal of Water and Health, 5(3), 455-466. https://doi.org/10.2166/wh.2007.041

Amponsah-Doku, F., Obiri-Danso, K., Abaidoo, R. C., \& Andoh, L. A. (2010). Bacterial contamination of lettuce and associated risk factors at production sites, markets and street food restaurants in urban and peri-urban Kumasi, Ghana. Scientific Research and Essays, 5(2), 217-23.

Ba, A., \& Aubry, C. (2011). Diversité et durabilité de l'agriculture urbaine: une nécessaire adaptation des concepts?. Norois, 221(4), 11-24. https://doi.org/10.4000/norois.3739

Ba, A., \& Cantoreggi, N. (2018). Agriculture urbaine et périurbaine (AUP) et économie des ménages agri-urbains à Dakar (Sénégal). International Journal of Environment, Agriculture and Biotechnology, 3(1), 195-207. https://doi.org/10.22161/ijeab/3.1.25 
Berger, C. N., Sodha, S. V., Shaw, R. K., Griffin, P. M., Pink, D., Hand, P., \& Franke,1 G. (2010). Fresh fruit and vegetables as vehicles for the transmission of human pathogens. Environmental Microbiology, 12, 2385-2397. https://doi.org/10.1111/j.1462-2920.2010.02297

Blaak, H., Lynch, G., Italiaander, R., Hamidjaja, R. A., \& De Roda, H. A. M. (2015). Multidrug-resistant and extended spectrum beta-lactamase-producing Escherichia coli in Dutch surface water and wastewater. PLoS One, 10(6), e0127752. https://doi.org/10.1371/journal.pone.0127752

César, J. C., Peres, A. M., Neves, C. P. D., Abreu, E. T. F., Mello, J. F., Moreira, A. N., \& Rodrigues, K. L. (2015). Microbiological assessment of lettuce salads and antimicrobial resistance of Staphylococcus spp. Nutricion Hospitalaria, 32(5), 2280-2285. https://doi.org/10.3305/nh.2015.32.5.9632

Cobbina, S. J., Kotochi, M. C., Korese, J. K., \& Akrong, M. O. (2013). Microbial Contamination in Vegetables at the Farm Gate Due to Irrigation with Wastewater in the Tamale Metropolis of Northern Ghana. Journal of Environmental Protection, 4, 676-682. http://dx.doi.org/10.4236/jep.2013.47078

Dongmo, T., Gockowski, J., Hernandez, S., Awono, L. D. K., \& Moudon, R. M. (2005). L'agriculture périurbaine à Yaoundé: ses rapports avec la réduction de la pauvreté, le développement économique, la conservation de la biodiversité et de l'environnement. Tropicultura, 23(3), 130-135.

Fondio, L., Kouame, C., Djidji, A. H., \& Traore, D. (2011). Caractérisation des systèmes de culture intégrant le gombo dans le maraîchage urbain et périurbain de Bouaké dans le Centre de la Côte d'Ivoire. International Journal of Biological and Chemical Sciences, 5(3), 1178-1789. https://doi.org/10.4314/ijbcs.v5i3.72251

Gomiero, T., Pimentel, D., \& Paoletti, M. G. (2011). Environmental impact of different agricultural management practices: conventional vs. organic agriculture. Critical Reviews in Plant Sciences, 30(1-2), 95-124. https://doi.org/10.1080/07352689.2011.554355

Guchi, B., \& Ashenafi, M. (2010). Microbial Load, Prevalence and Antibiograms of Salmonella and Shigella in Lettuce and Green Peppers. Ethiopian Journal of Health Sciences, 20(1), 41-48. https://doi.org/10.4314/ejhs.v20i1.69431

Holvoet, K., Sampers, I., Seynnaeve, M., \& Uyttendaele, M. (2014a). Relationships among hygiene indicators and enteric pathogens in irrigation water, soil and lettuce and the impact of climatic conditions on contamination in the lettuce primary production. International Journal of Food Microbiology, 171, 21-31. https://doi.org/10.1016/j.ijfoodmicro.2013.11.009

Holvoet, K., Sampers, I., Seynnaeve, M., Jacxsens, L., \& Uyttendale, M. (2014b). Agricultural and Management Practices and Bacterial Contamination in Greenhouse versus Open Field Lettuce Production. International Journal of Environmental Research and Public Health, 12, 32-63. https://doi.org/10.3390/ijerph120100032

Jensen, D. A., Friedrich, L. M., Harris, L. J., Danyluk, M. D., \& Schaffner, D. W. (2015). Cross contamination of Escherichia coli $\mathrm{O} 157: \mathrm{H} 7$ between lettuce and wash water during home-scale washing. Food Microbiology, 46, 428-33. https://doi.org/10.1016/j.fm.2014.08.025

Kenmongue, G. R. K., Rosillon, F., Mpakam, H. G., \& Nono, A. (2010). Enjeux sanitaires, socioéconomiques et environnementaux liés à la réutilisation des eaux usées dans le maraîchage urbain : cas du bassin versant de l'Abiergué (Yaoundé-Cameroun). Vertigo, 10, 2. https://doi.org/10.4000/vertigo.10323

Keraita, B., Drechsel, P., \& Konradsen, F. (2008). Perceptions of farmers on health risks and risk reduction measures in wastewater irrigated urban vegetable farming in Ghana. Journal of Risk Research, 11(8), 1047-1061. https://doi.org/10.1080/13669870802380825

Koffi, N. R., Assi, C. B. J., Assemand, E. F., Wognin, A. S., \& Koussemon, M. (2012). Origine des témoins de contamination fécale de l'eau d'arrosage de la laitue (Lactuca sativa) cultivée dans la zone péri-urbaine d'Abidjan. Journal of Applied Biosciences, 52, 3669-3675.

Koffi, N. R., Assi, C. B. J., Koussemon, M., Wognin, A. S., \& Coulibaly, N. (2011). Potential Enterobacteria risk factors associated with contamination of lettuce (Lactuca sativa) grown in the peri urban area of Abidjan (Côte d'Ivoire). International Journal Biological and Chemical Sciences, 5(1), 279-290. https://doi.org/10.4314/ijbcs.v5i1.68104

Kroupitski, Y., Golberg, D., Belausov, E., Pinto, R., Swartzberg, D., Granot, D., \& Sela, S. (2009). Internalization of Salmonella enterica in leaves is induced by light and involves chemotaxis and penetration through open stomata. Applied and Environmental Microbiology, 75, 6076-6086.

https://doi.org/10.1128/AEM.01084-09 
Loudit, S. M. B., Ndong, A. N., \& Francis, F. (2017). Le maraîchage périurbain à Libreville et Owendo (Gabon) : pratiques culturales et durabilité. Cahiers Agricultures, 26, 45002. https://doi.org/10.1051/cagri/2017026

Maffei, D. F., Silveira, N. F. A., \& Catanozi, M. P. L. M. (2013). Microbiological quality of organic and conventional vegetables sold in Brazil. Food Control, 29, 226-230. http://dx.doi.org/10.1016/j.foodcont.2012.06.013

Mngoli, K. C., \& Ng'ong'ola-Manani, T. A. (2014). Microbiological quality of fresh lettuce sold at Lilongwe market, Malawi: Does purchasing time matter? African Journal of Microbiology Research, 8(6), 491-495. https://doi.org/10.5897/AJMR2013.6267

Mohammad, R.N., Moayed, A., Fariba, S., \& Jahangir, A. (2013). Assessment of the microbiological safety of salad vegetables from different Restaurants in Ilam. Journal of Paramedical Sciences, 4(2), 111-115.

Pereira, E. L., Rodrigues, A., \& Ramalhosa, E. (2013). Influence of working conditions and practices on fresh-cut lettuce salads quality. Food Control, 33, 406-412. https://doi.org/10.1016/j.foodcont. 2013.03.021

Petterson, S. R., Ashbolt, N. J., \& Sharma, A. (2010). Microbial risks from wastewater irrigation of salad crops: a screening-level risk assessment. Journal of Food Science, 75(5), 283-290.

RGPH. (2014). Résultats Recensement Général de Population et de Habitat, 6p.

Schikora, A., Virlogeux-Payant, I., Bueso, E., Garcia, A. V., Nilau, T., Charrier A., Pelletier, S., Menanteau, P., Baccarini, M., Velge, P., \& Hirt, H. (2011). Conservation of Salmonella Infection Mechanisms in Plants and Animals. PLoS One, 6(9), e24112. https://doi.org/10.1371/journal.pone. 0024112.

Soendjojo, E. (2012). Is local produce safer? Microbiological quality of fresh lettuce and spinach from grocery stores and farmers' markets. Journal of Purdue Undergraduate Research, 2, 54-63. https://doi.org/10.5703/jpur.02.1.09

Somda, N. S., Isidore, B. O. J., Traoré, O., Bassolé, I. H. N., Traoré, Y., Barro, N., \& Savadogo, A. (2017). Serotyping and antimicrobial drug resistance of Salmonella isolated from lettuce and human diarrhea samples in Burkina Faso. African Journal of Infectious Diseases, 11(2), 24-30. https://doi.org/10.21010/ajid.v11i2.4

Soro, S., Doumbouya, M., \& Koné, D. (2008). Potentiel infectieux des sols de cultures de tomate (Lycopersicon esculentum) sous abri et incidence de l'âge de repiquage sur la vigueur des plants vis-à-vis de Pythium sp. à Songon-Dabou en Côte d'Ivoire. Tropicultura, 26(3), 173-178.

Traoré, O., Nyholm, O., Siitonen, A., Bonkoungou, J. I., Traoré, A. S., Barro N., \& Haukka K. (2015). Prevalence and diversity of Salmonella enterica in water, fish and lettuce in Ouagadougou, Burkina Faso. BMC Microbiology, 15,151. https://doi.org/10.1186/s12866-015-0484-7

Wadamori, Y., Fam, J., Hussain, M. A., \& Gooneratne, R. (2016). Microbiological risk assessment and antibiotic resistance profiling of fresh produce from different soil enrichment systems: A preliminary study. Cogent Food \& Agriculture, 2, 1274281. http://dx.doi.org/10.1080/23311932.2016.1274281

Wognin, A. S., Ouffoue, K. S., Assemand, E. F., Tano, K., \& Koffi-Nevry, R. (2013). Perception des risques sanitaires dans le maraîchage à Abidjan, Côte d'Ivoire. International Journal of Biological and Chemical Science, 7(5), 1829-1837. https://doi.org/10.4314/ijbcs.v7i5.4

Woldetsadik, D., Drechsel, P., Keraita, B., Itanna, F., Erko, B., \& Gebrekidan, H. (2017). Microbiological quality of lettuce (Lactuca sativa) irrigated with wastewater in Addis Ababa, Ethiopia and effect of green salads washing methods. International Journal of Food contamination, 4, 3. https://doi.org/10.1186/s40550-017-0048-8

Zah, B. T. (2015). Impact de la migration sur la démographie en Côte d'Ivoire. Revue de géographie du laboratoire Leïdi, 13, 284-300.

Zhang, J. M. D., Oxinos, G., \& Maher, J. H. (2009). The effect of fruit and vegetable powder mix on hypertensive subjects: a pilot study. Journal of Chiropractic Medicine, 8, 101-106. https://doi.org/10.1016/j.jcm.2008.09.004

\section{Copyrights}

Copyright for this article is retained by the author(s), with first publication rights granted to the journal.

This is an open-access article distributed under the terms and conditions of the Creative Commons Attribution license (http://creativecommons.org/licenses/by/4.0/). 